\title{
Diurnal, seasonal, and vertical distribution of carbon monoxide levels and their potential sources over a semi-arid region, India
}

\author{
Elijabetthamma BUSA, Balakrishnaiah GUGAMSETTY, Raja Obul Reddy KALLURI, \\ Rama Gopal KOTALO*, Chakradhar Rao TANDULE, Lokeswara Reddy THOTLI, \\ Manjunatha CHAKALA and Surya Nagi Reddy PALLE
}

\author{
Aerosol and Atmospheric Research Laboratory, Department of Physics, Sri Krishnadevaraya University, Anantapur \\ - 515003 , A.P., India. \\ * Corresponding author:email: krgverma@yahoo.com
}

Received: December 23, 2019; accepted: October 23, 2020

\begin{abstract}
RESUMEN
El presente estudio se enfoca a la investigación de la variabilidad tanto vertical como cercana a la superficie de las concentraciones de monóxido carbono (CO), así como de sus fuentes potenciales, obtenidas tanto in situ como a partir de datos satelitales del instrumento MOPITT (Measurement of Pollution in the Troposphere) sobre una región semiárida (Anantapur, India), de enero de 2016 a diciembre de 2017. La variación diurna del CO muestra picos pronunciados durante la mañana (de 07:00 a 09:00 horas) y la tarde (de 19:00 a 21:00 horas) asociados con actividades antrópicas locales y el impacto de la altura de la capa de mezcla, así como bajas concentraciones en el día (12:00 a 15:00 horas). Los bajos niveles durante las horas de la tarde pueden deberse al incremento de la altura de la capa de mezcla y al decremento de las fuentes antrópicas. La media estacional del $\mathrm{CO}$ no mostró variaciones evidentes, con los niveles más altos observados durante el invierno ( $329 \pm 52 \mathrm{ppbv})$, seguido por el premonzón ( $327 \pm 57 \mathrm{ppbv})$, el postmonzón $(234 \pm 36$ ppbv) y el monzón (192 $\pm 22 \mathrm{ppbv})$. Los niveles altos de CO observados durante el invierno se atribuyen a emisiones antrópicas y a la escasa altura de la capa de mezcla. La distribución vertical del CO mostró picos secundarios en presencia de niveles de presión altos (300-200 hPa) durante el invierno, el premonzón y el postmonzón, lo cual indica que hay transporte desde diferentes fuentes regionales. El análisis de la concentración ponderada de la trayectoria (CWT, por sus siglas en inglés) de la masa de aire, obtenida a partir del modelo HYSPLIT (Hybrid Single Particle Lagrangian Integrated Trajectory) confirma de manera razonable estos hallazgos. El presente estudio sugiere que, con excepción de la época del monzón, las masas de aire transportadas desde la región de la cuenca indogangética también contribuyen al incremento de las concentraciones de $\mathrm{CO}$ en el sitio receptor.
\end{abstract}

\begin{abstract}
The present study focuses on the investigation of both near-surface and vertical variability of carbon monoxide $(\mathrm{CO})$ concentrations and their potential sources obtained from both in situ and satellite Measurements of Pollution in the Troposphere (MOPITT) over a semiarid region (Anantapur, India) from January 2016 to December 2017. The diurnal variation of CO shows sharp morning (07:00-09:00 LT) and evening (07:0009:00 LT) peaks associated to local anthropogenic activities as well as the impact of the mixed layer height, and low concentrations during daytime (12:00-15:00 LT). The low levels during afternoon hours may be due to the increase of the mixed layer height and the decrease of anthropogenic sources. The seasonal mean $\mathrm{CO}$ showed no obvious variation, with highest levels observed in winter $(329 \pm 52 \mathrm{ppbv})$, followed by the pre-monsoon $(327 \pm 57 \mathrm{ppbv})$, post-monsoon $(234 \pm 36 \mathrm{ppbv})$ and monsoon $(192 \pm 22 \mathrm{ppbv})$. The high levels of $\mathrm{CO}$ during the winter are attributed to increased emissions from anthropogenic sources and a shallow mixed layer height. The vertical distribution of CO showed secondary peaks at high-pressure levels (300-200 hPa)
\end{abstract}


during winter, pre-monsoon, and post-monsoon, which indicates $\mathrm{CO}$ transport from different source regions. These findings are reasonably confirmed through the air mass Concentrated Weighted Trajectory (CWT) analysis obtained from the Hybrid Single Particle Lagrangian Integrated Trajectory (HYSPLIT) model. This study suggests that except for the monsoon, air masses transported from Indo-Gangetic Basin region also contribute to the enhancement of $\mathrm{CO}$ concentrations at the receptor site.

Keywords: carbon monoxide, MOPITT, HYSPLIT, semiarid.

\section{Introduction}

Rapid industrial development and economic growth in South Asia has contributed to increasing emissions of trace gases and particulate matter in the atmosphere, which have a strong impact on both global and regional environment (Akimoto, 2003; Pozzer et al., 2012). The nature and extent of these emissions are employed to develop policies to mitigate their impact. Biomass and fossil fuel burning, as well as vehicular emissions are the most important sources for the formation of carbon monoxide (CO), though a lower amount of CO derives from the ocean and geological activity (Reddy et al., 2008). This gas indirectly contributes to global warming and also reduces the blood's ability to carry oxygen to body organs. It is known as a precursor of ozone $\left(\mathrm{O}_{3}\right)$ and is a source of $\mathrm{CO}_{2}$. In addition, $\mathrm{CO}$ is responsible for the direct surface emission and oxidation of hydrocarbons (Duncan et al., 2007). It can react chemically with other atmospheric constituents (primarily the hydroxyl radical, $\mathrm{OH}^{\cdot}$ ) that would otherwise destroy methane. CO's chemical lifetime is relatively short and spatially variable in concentration, depending on the $\mathrm{OH}$ concentrations (Lawrence et al., 2003).

Few studies of $\mathrm{CO}$ concentrations have been conducted in India by using in-situ techniques (Lal et al., 2000, 2012; Naja and Lal, 2002; Sahu et al., 2006; Beig et al., 2007; Mallik and Lal, 2014; Sarangi et al., 2014). Apart from real-time measurements, satellite studies have also been performed to study the dynamical effects and long-term trends of $\mathrm{CO}$ concentrations in the troposphere (Kar et al., 2004, 2008, 2010; Ghude et al., 2011; Kumar et al., 2013; Worden et al., 2013; Girach and Nair, 2014; Sheel et al., 2014; Yoon and Pozzer, 2014). For better understanding the variations of CO concentrations and their potential sources over a semiarid region, we analyzed CO data both in-situ and from the MOPITT instrument onboard the Terra satellite.
The main objective of the present study is to analyze the diurnal and seasonal variation of $\mathrm{CO}$ concentrations during the period 2016-2017. The vertical profiles of $\mathrm{CO}$ originating from the MOPITT instrument are examined during the study period. Source apportionment studies are also conducted with the help of the Moderate Resolution Imaging Spectroradiometer (MODIS) fire counts and the Hybrid Single Particle Lagrangian Integrated Trajectory (HYSPLIT) model for the identification of sources' origins. Finally, a comparison study is carried out for $\mathrm{CO}$ in different parts of the Indian region.

\section{Site description and instrumentation}

\subsection{Site description}

Anantapur is a very dry continental region which receives low precipitation throughout the year, with the greatest rainfall occurring during the monsoon (Reddy et al., 2016). The sampling site is surrounded by a number of cement plants, slab polishing, lime kilns, and brickworks; however, national highways NH 7 and NH 205 also constitute the largest sources of anthropogenic particles (Gopal et al., 2016). The climate is governed by monsoon-influenced marine weather systems. The entire study period is divided into four seasons: winter (December-February), pre-monsoon (March-May), monsoon (June-August), and post-monsoon (September-November). The real-time near-surface CO concentration levels were measured at the Department of Physics, Sri Krishnadevaraya University (SKU, $14.62^{\circ} \mathrm{N}, 77.65^{\circ}$ E, 331 masl), located at the southern edge of Anantapur city (Fig. 1).

\subsection{Near-surface CO}

Near-surface CO concentrations are continuously monitored using the $\mathrm{CO}$ monitor analyzer (APMA370, Horiba, Germany). The analyzer worked adequately based on the principle of non-dispersive 


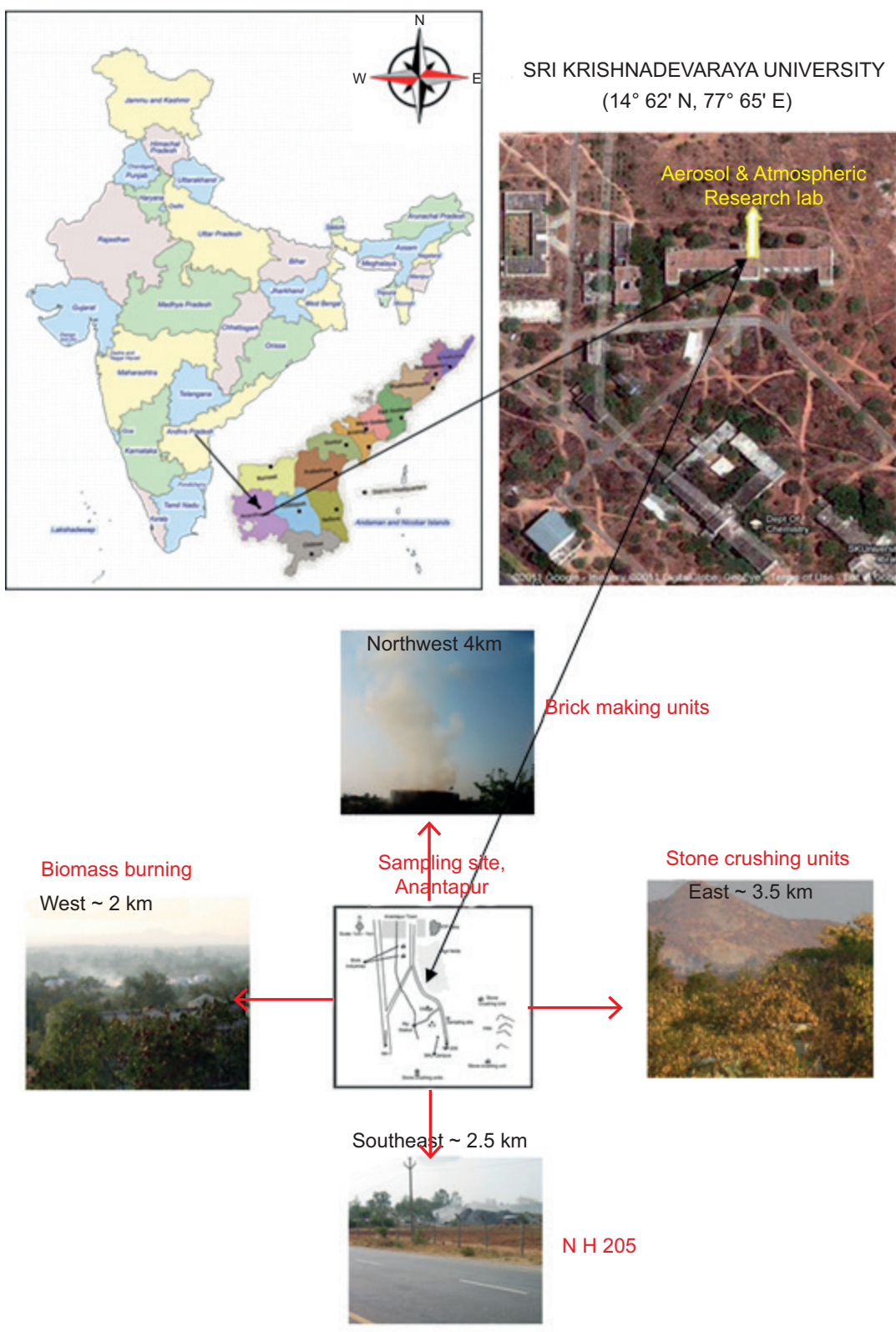

Fig. 1. Location of the Sri Krishnadevaraya University campus area in Anantapur. The monitoring site-building in the SK University campus is indicated with an arrowhead in the satellite aerial view.

infrared absorption. It uses the AS-type detector from which extremely high-accurate results were obtained without any interference components. The performance, efficiency, accuracy, calibration and advantages of analyzers have been described elsewhere (Reddy et al., 2008). However, when the concentration of the interference gas changes (since there is a time gap for the sample and reference gases to reach the measurement cell) an influence due to the interference gas may occur. In order to address this problem (such as a change in the interference gas concentration) APMA-370 measures the concentration of the interference gas component with an interference compensation detector and corrects its influence on the 
output signal of the measurement detector. To reduce uncertainty in thr levels, the filter was replaced every 3-4 weeks, and calibration was performed at regular intervals. The $\mathrm{CO}$ analyzer was zero calibrated with zero air generator, and span calibration was performed with the help of a multipoint calibrator. The linearity of the instrument was checked with an internal zero gas and five NIST traceable CO standards $(60,250,300,500$, and $1000 \mathrm{ppb})$. In addition, daily instrument checks were performed using a $500 \mathrm{ppb}$ CO standard and zero internal gas.

\subsection{MOPITT}

The vertical distribution of $\mathrm{CO}$ mixing ratios was obtained from the Measurements of Pollution in the Troposphere (MOPITT) level 3, version 8 instrument, which is aboard the EOS Terra satellite and has a horizontal spatial resolution of $22 \times 22 \mathrm{~km}$ and a track swath of $640 \mathrm{~km}$. Daytime data products are archived on a $1^{\circ} \times 1^{\circ}$ latitude-longitude grid in different pressure levels $(900,800,700,600,500$, $400,300,200$, and $100 \mathrm{mb})$. More details about the retrieval algorithm and validation are available in Pan et al. (1995) and Emmons et al. (2010).

\subsection{Aethalometer}

Real-time measurements of the black carbon (BC) mass concentration were collected using a seven-wavelength Aethalometer (AE 42, Magee Scientific, USA). BC was collected continuously (time resolution of $5 \mathrm{~min}$ ) from January 2016 to December 2017. The aethalometer measures optical attenuation due to particles deposited on a quartz filter (filter-based technique) at seven wavelengths: $370,470,520,590$, 660,880 , and $950 \mathrm{~nm}$, with flow rate maintained at 3 LPM. The BC measured at $880 \mathrm{~nm}$ is considered as the standard, since $\mathrm{BC}$ is the principal light absorber at that wavelength. More details about the uncertainty in the estimation of BC mass concentration with an Aethalometer and correction factors were well documented by Hansen et al. (1984) and Weingartner et al. (2003).

\subsection{Concentration weighted trajectory (CWT) anal-} ysis and MODIS fire counts

Concentration Weighted Trajectory (CWT) analysis was performed to identify the relative contribution of potential source regions to CO levels (Nazeer et al., 2018; Kalluri et al., 2019, 2020a). Many researchers have also used HYSPLIT to identify the pollution transport process in different regions. In the CWT technique, trajectories reaching over the study site are weighted based on the mean concentration measured at the location during the arrival of the trajectory. In this technique, each grid cell is assigned a concentration obtained by averaging associated concentrations that crossed the grid cell:

$$
C_{i j}=\frac{1}{\sum_{l=1}^{M} \tau_{i j l}} \sum_{l=1}^{M} C_{l} \tau_{i j l}
$$

where $C i j$ is the average weighted concentration in the $i j^{\text {th }}$ cell, 1 is the index of the trajectory, $M$ is the total number of trajectories, $\mathrm{Cl}$ is the concentration observed in the trajectory endpoint, and $\tau i j l$ is the time spent in the $i j^{\text {th }}$ cell by the trajectory 1 (Seibert et al., 1994). The fire-count data was obtained from the Fire Information for Resource Management System (FIRMS, http://firms.modaps.eosdis.nasa. gov/firemap/). MODIS provides fire information based on a brightness temperature algorithm at the 4- and 11-mm channels. Confidence levels ranging from 0 to $100 \%$, were used to assign one of three fire classes to all the fire pixels. Further details about the principle and retrieval algorithm are available in Giglio et al. (2003). In the present study, data with high confidence $(>80 \%)$ was considered.

\section{Results and discussion}

\subsection{Diurnal and monthly variation of $C O$}

The observed diurnal variation of $\mathrm{CO}$ is characterized by two peaks during the morning (07:00-09:00 LT) and night hours (21:00-23:00 LT). Low concentrations are noticed during daytime (12:00-15:00 LT) (Fig. 2). The diurnal variation of $\mathrm{CO}$ shows a predominant peak during the morning as compared to the evening, which may be due to variations in the mixed layer height and anthropogenic sources. In contrast, during the evening, traffic emissions remain almost the same, but the mixed layer height decreases, which results in higher CO concentrations. During the night, CO levels showed little variation in comparison to daytime. The diurnal variation with low concentration during the afternoon could partly be affected by lower anthropogenic activities, photooxidation processes, and a high mixed layer height. A similar diurnal variation of $\mathrm{CO}$ was found in other regions 


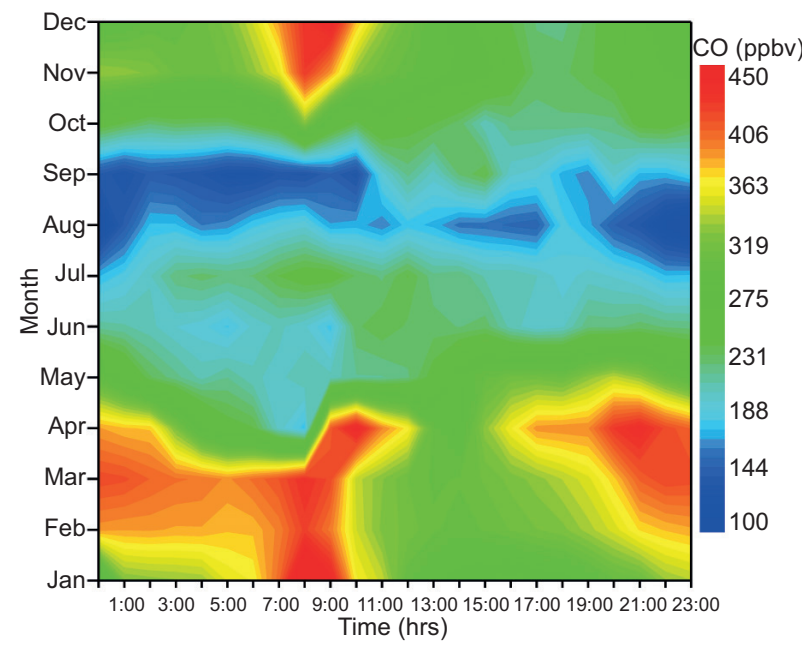

Fig. 2. Contour plot of diurnal and monthly variations of $\mathrm{CO}$ concentrations over Anantapur.

of India, such as Ahmadabad (Lal et al., 2000), Chile (Rappengluck et al., 2005), Pune (Beig et al., 2007), Kanpur (Gaur et al., 2014), Agra (Verma et al., 2017), and Kathmandu valley (Bhardwaj et al., 2018).

The in-situ measured CO surface levels have no obvious seasonal variability. Monthly mean maximum and minimum of CO were noted in March (324 $\pm 59 \mathrm{ppbv})$ and August $(155 \pm 28 \mathrm{ppbv})$. The monthly maximum $\mathrm{CO}$ concentration was observed in March, on account of anthropogenic emissions from agricultural fields (north) close to the measurement site. Crop residues are burned by farmers to clear agricultural fields to enhance the next crops yield, which contributes to a higher amount of CO (Dalvi et al., 2006). The seasonal variation of $\mathrm{CO}$ showed its highest levels in winter ( $329 \pm 52 \mathrm{ppbv})$ followed by pre-monsoon ( $327 \pm 57 \mathrm{ppbv})$, post-monsoon (234 \pm $36 \mathrm{ppbv})$ and monsoon (192 $\pm 22 \mathrm{ppbv})$. The highest levels of CO during winter may be attributed to: (1) weak photochemical removal, (2) an increase in local emission sources, and (3) low wind speeds that cause entrapment of pollutants near the surface. The lowest concentration was observed during the monsoon season due to winds blowing from the Arabian Sea.

\subsection{Vertical variability of $\mathrm{CO}$ retrieved from $\mathrm{MO}$ - PITT and synoptic meteorology}

Figure 3 shows the vertical distribution of $\mathrm{CO}$ mixing ratios in different months retrieved from the MOPITT

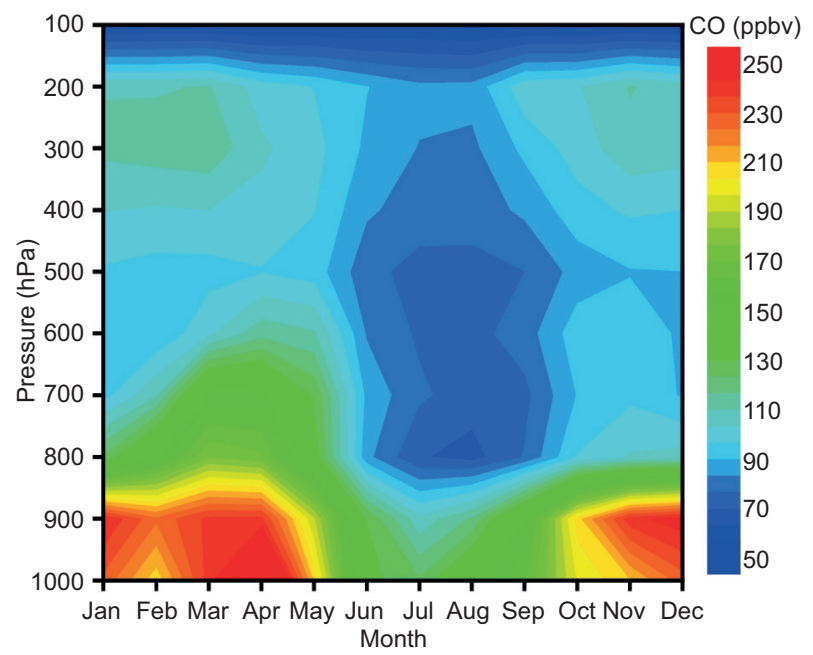

Fig. 3. Monthly variation of MOPITT retrieved CO profiles over the measurement location.

instrument over Anantapur. In general, the $\mathrm{CO}$ mixing ratio decreases with height from 1000 to $100 \mathrm{hPa}$; however, the surface $\mathrm{CO}$ mixing ratio was stronger at lower altitudes in all months. $\mathrm{CO}$ exhibits distinct seasonal variations near the surface (1000 hpa) with highest levels during the pre-monsoon $(244 \pm 37$ ppbv) and lowest in the monsoon (134 \pm 10 ppbv). The pattern of seasonal variation at low altitudes $(1000 \mathrm{hPa})$ observed by MOPITT was consistent with ground-level measurements. However, at low pressure levels (low pressure corresponds to a higher altitude), $\mathrm{CO}$ mixing ratios were found to be low during the monsoon due to washout processes, air masses originating from the Arabian Sea and less human activity. During the pre-monsoon, numerous fires spotted in central India were identified by MODIS. The continental air masses dominated during winter and pre-monsoon, resulting in higher $\mathrm{CO}$ concentrations at high altitudes (200 hpa). Vertical wind distribution an important cause of the vertical mixing of $\mathrm{CO}$ in the upper troposphere. Figures 4 and 5 represent the seasonal vertical wind and horizontal wind circulation at 850 and $500 \mathrm{hPa}$ over the observational site, obtained from the European Centre for Medium-Range Weather Forecasts (ECMWF)-interim reanalysis and Modern-Era Retrospective Analysis For Research And Applications (MERRA) data during 2016-2017. The color bar in the figures represents wind speed, and the arrow indicates the wind direction and the 

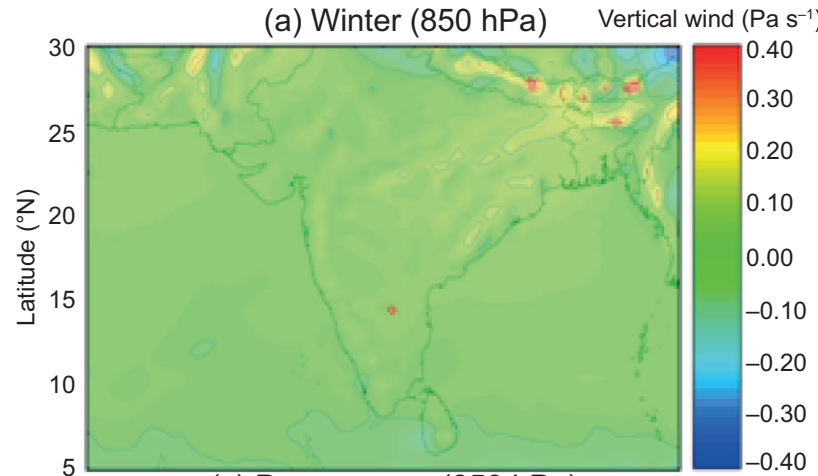

(b) Winter@850hPa
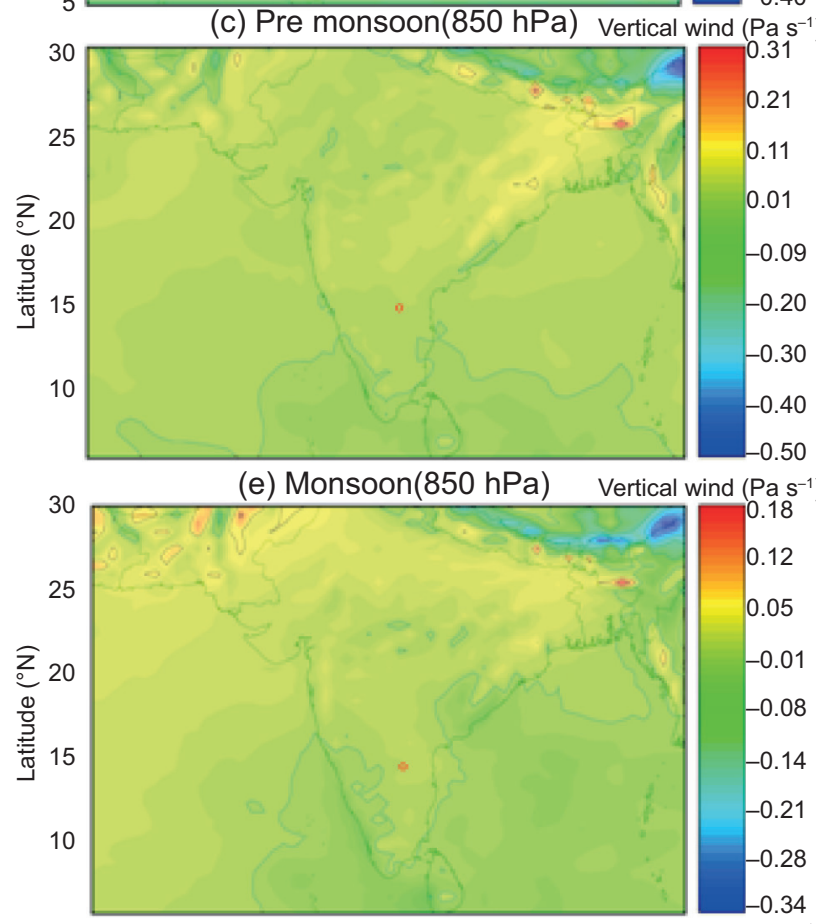

$\left(\mathrm{Pa} \mathrm{s}^{-1}\right)$
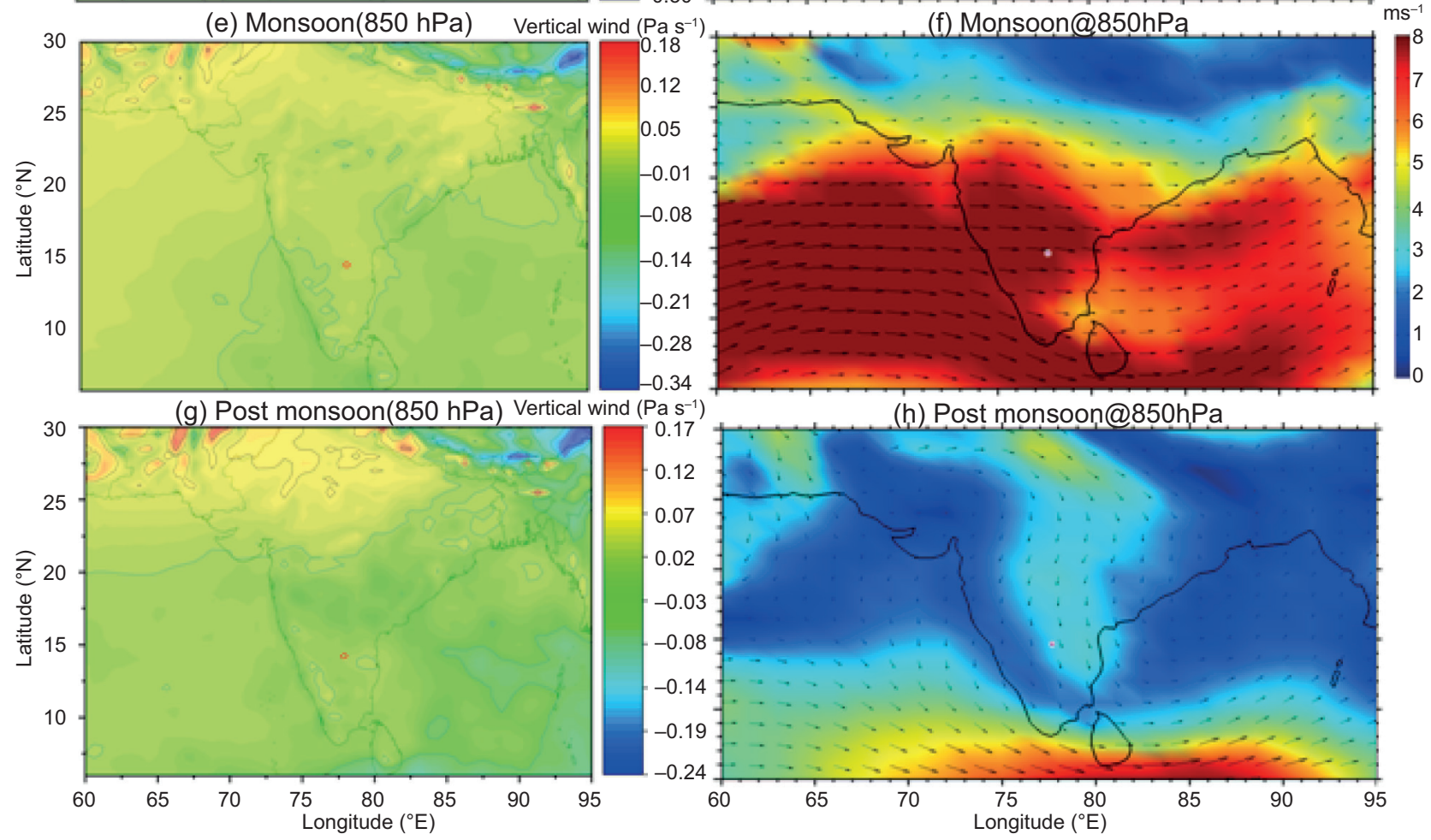

$\left(\mathrm{Pa} \mathrm{s}^{-1}\right)$
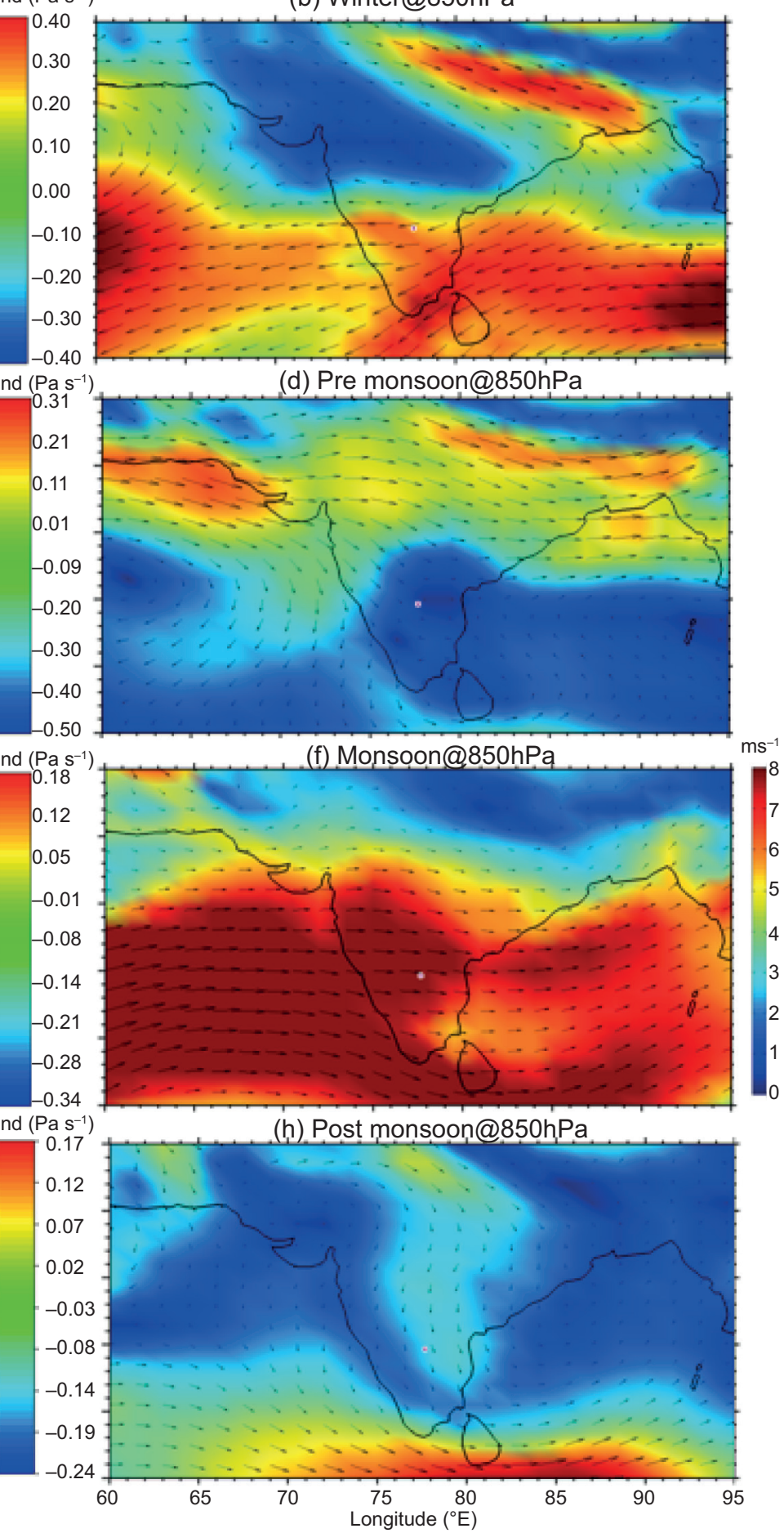

(h) Post monsoon@850hPa

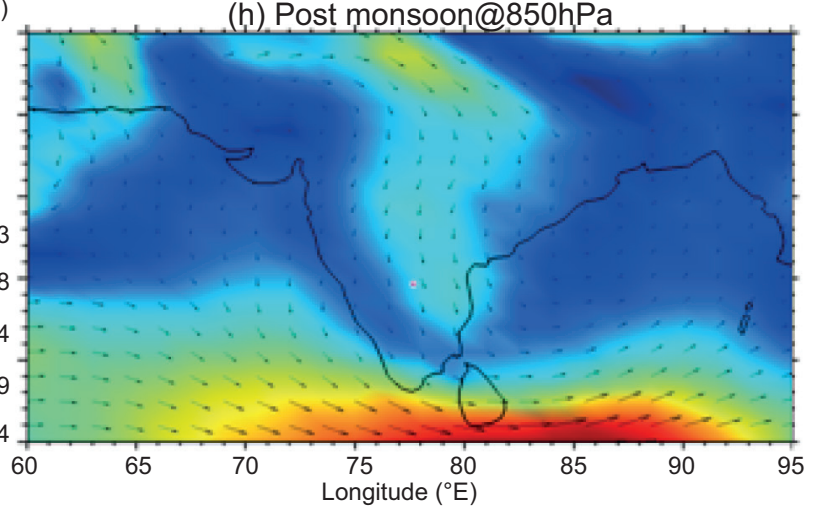

Fig. 4. Seasonal variation of vertical and horizontal winds at $850 \mathrm{hPA}$. The left panel indicates vertical velocities $\left(\mathrm{Pa} \mathrm{s}^{-1}\right)$, while the right panel indicates horizontal winds $\left(\mathrm{m} \mathrm{s}^{-1}\right)$ and the circle shows the measurement location. 
(a) Winter (500 hPa) Vertical wind $\left(\mathrm{Pa} \mathrm{s}^{-1}\right)$

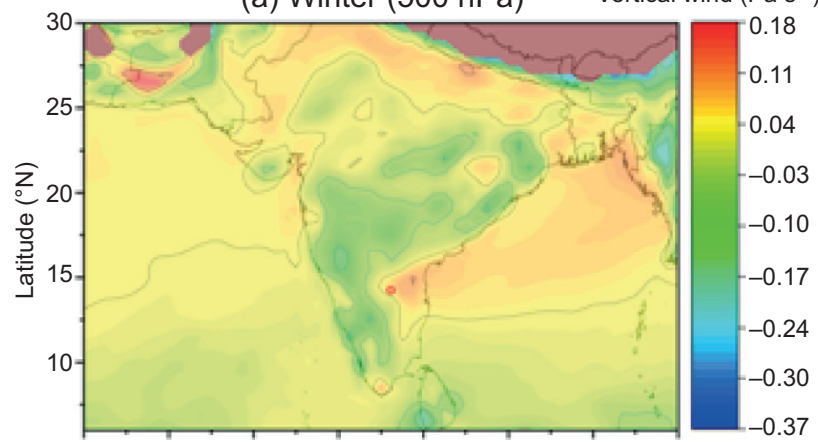

(c) Pre monsoon $(500 \mathrm{hPa})$ Vertical wind $\left(\mathrm{Pa} \mathrm{s}^{-1}\right)$
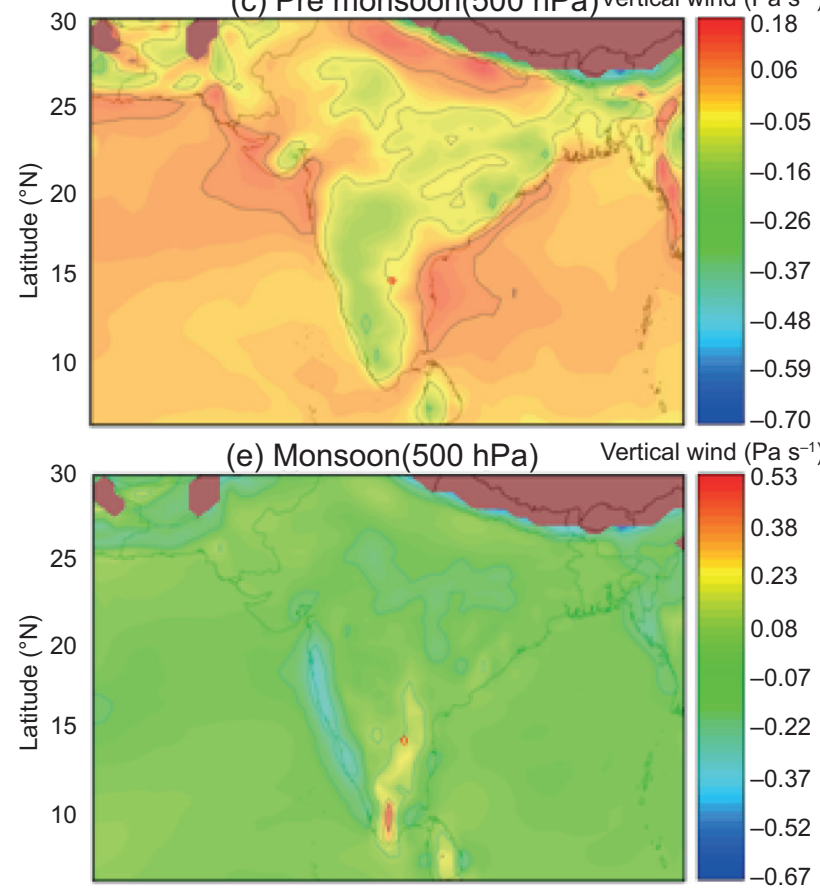

(g) Post monsoon(500 hPa) Vertical wind $\left(\mathrm{Pa} \mathrm{s}^{-1}\right)$

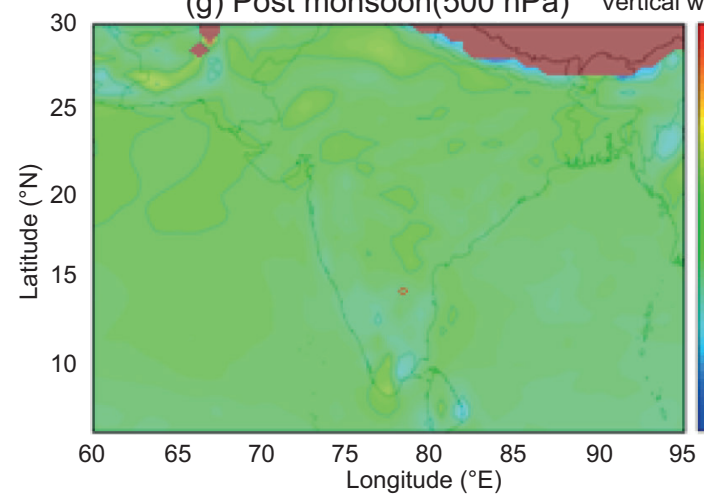

( 0.53
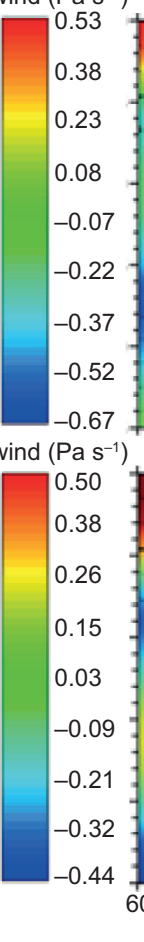

(b) Winter@500hPa

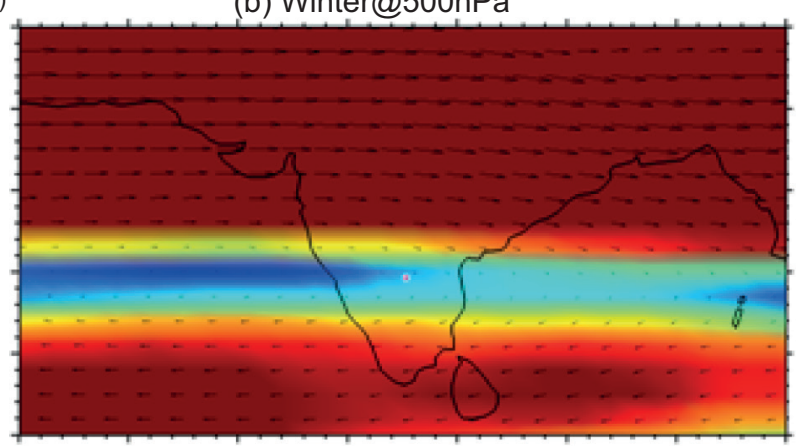

(d) Pre monsoon@500hPa

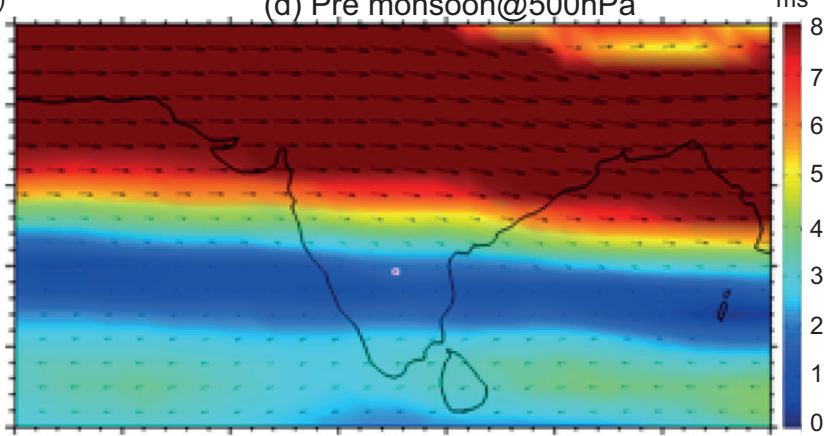

(f) Monsoon@500hPa

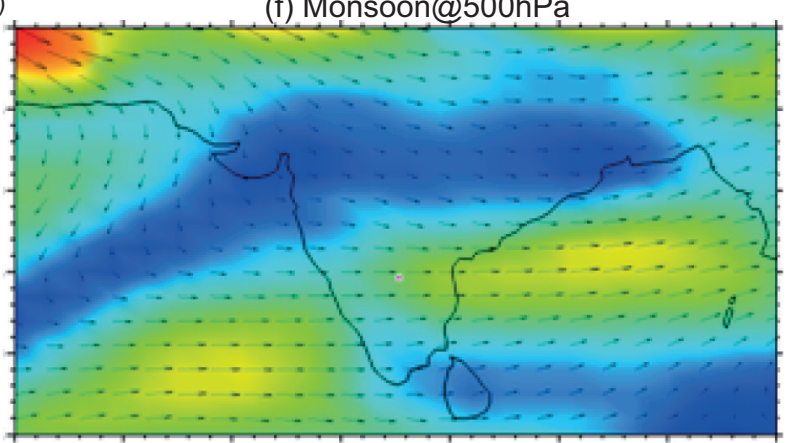

(h) Post monsoon@500hPa

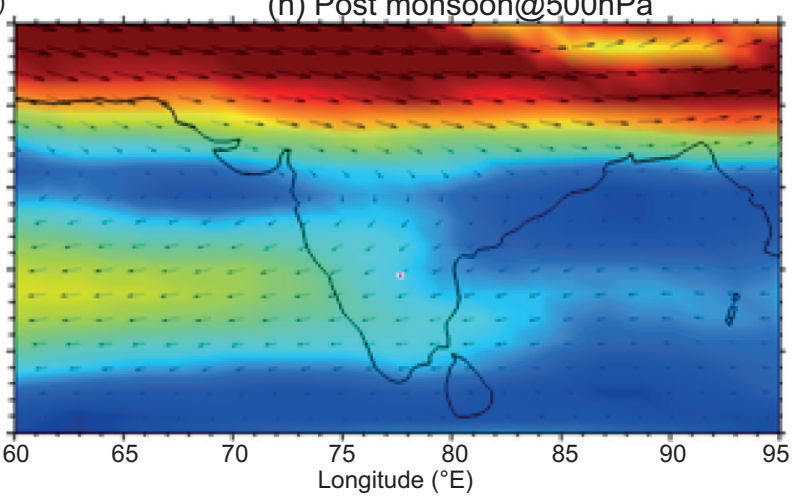

Fig. 5. Same as Figure 4, but for $500 \mathrm{hPa}$. 
white square indicates the observation site. The wind during winter, pre-monsoon and post-monsoon at 850 hpa was originated from the northwest and passed through central India before reaching the observation site. The northwestern winds are responsible for the transport of $\mathrm{CO}$ from urban locations in central India. During the post-monsoon, a synoptic wind pattern originated from the central Indo-Gangetic Basin (IGB), which is due to an additional source of $\mathrm{CO}$ mixing ratios observed at low pressure levels over the measurement location. During the monsoon, season winds generally originate from the Arabian Sea and low anthropogenic activities, which are responsible for low $\mathrm{CO}$ mixing ratios over the measurement location. Figures 4 and 5 show that the observed $\mathrm{CO}$ concentration at high altitudes during winter and the post-monsoon is attributed to the vertical transport of surface level CO in the mid and upper troposphere. This is due to the fact that vertical velocities are negative and much weaker (downward motion) during winter and the post-monsoon seasons over the observational site, as seen in Figure 4a, g.

\subsection{Relation between $B C$ and $C O$}

$\mathrm{BC}$ and $\mathrm{CO}$ are a result of the combustion of fossil fuel and biomass burning, and they have a relatively long atmospheric lifetime. Both are inert chemically in a timeframe of a few hours, thus, chemical reactions are not expected to change their concentrations during air mass transport between emission sources and measurement sites (Baumgardner et al., 2002). The scatter plots of BC and CO for different seasons are shown in Figure 6a-d. The correlation coefficient between $\mathrm{CO}$ and $\mathrm{BC}$ was found to be $0.42,0.43,0.39,0.37$ for winter, pre-monsoon, monsoon and post-monsoon, respectively. The moderate
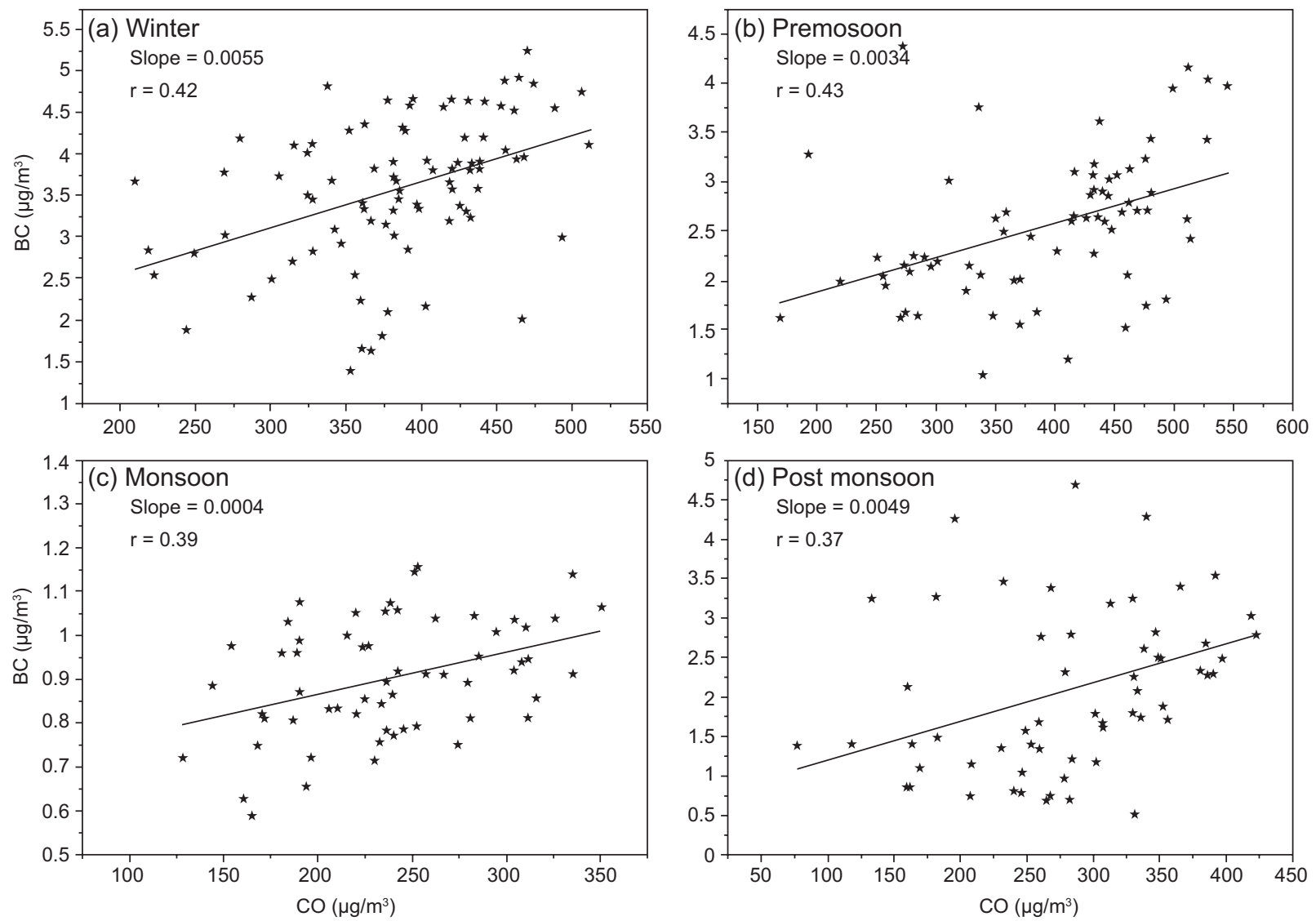

Fig. 6. Scatter plot of the relation between black carbon and CO for (a) winter, (b) pre-monsoon, (c) monsoon, and (d) pos-monsoon. 
correlation between $\mathrm{CO}$ and $\mathrm{BC}$ was influenced both by emissions from local activities and transport over the observation site. As suggested by previous studies (Kalluri et al., 2017, 2020b; Gopal et al., 2014, 2017) long-range transport could be an important source of absorbing aerosols (except during the monsoon) over the measurement location.

\subsection{Source apportionment and MODIS fire counts} In order to identify the $\mathrm{CO}$ transport pathways, isentropic CWT cluster analysis was derived based on air mass back-trajectories data at an altitude of $500 \mathrm{~m}$ above the ground level using the HYSPLIT model and the MODIS Fire Mapper products to give an idea about the location and extent of fires for the entire period (Figs. 7 and 8) (Draxler et al., 1997). Local sources contribute actively to the measured $\mathrm{CO}$, whereas polluted air originated from upwind high industrialized regions also play a part in the enhancement of $\mathrm{CO}$ as is evident from the observed trajectories during winter (Fig. 8a).

Furthermore, a widespread of active fires was observed by MODIS in areas of the northeastern regions compared to other regions during the pre-monsoon, indicating the significant influence of biomass burning in the production of $\mathrm{CO}$ and its concentration levels in the troposphere (Figs. $7 \mathrm{~b}$ and $8 \mathrm{~b})$. A similar condition occurs during the

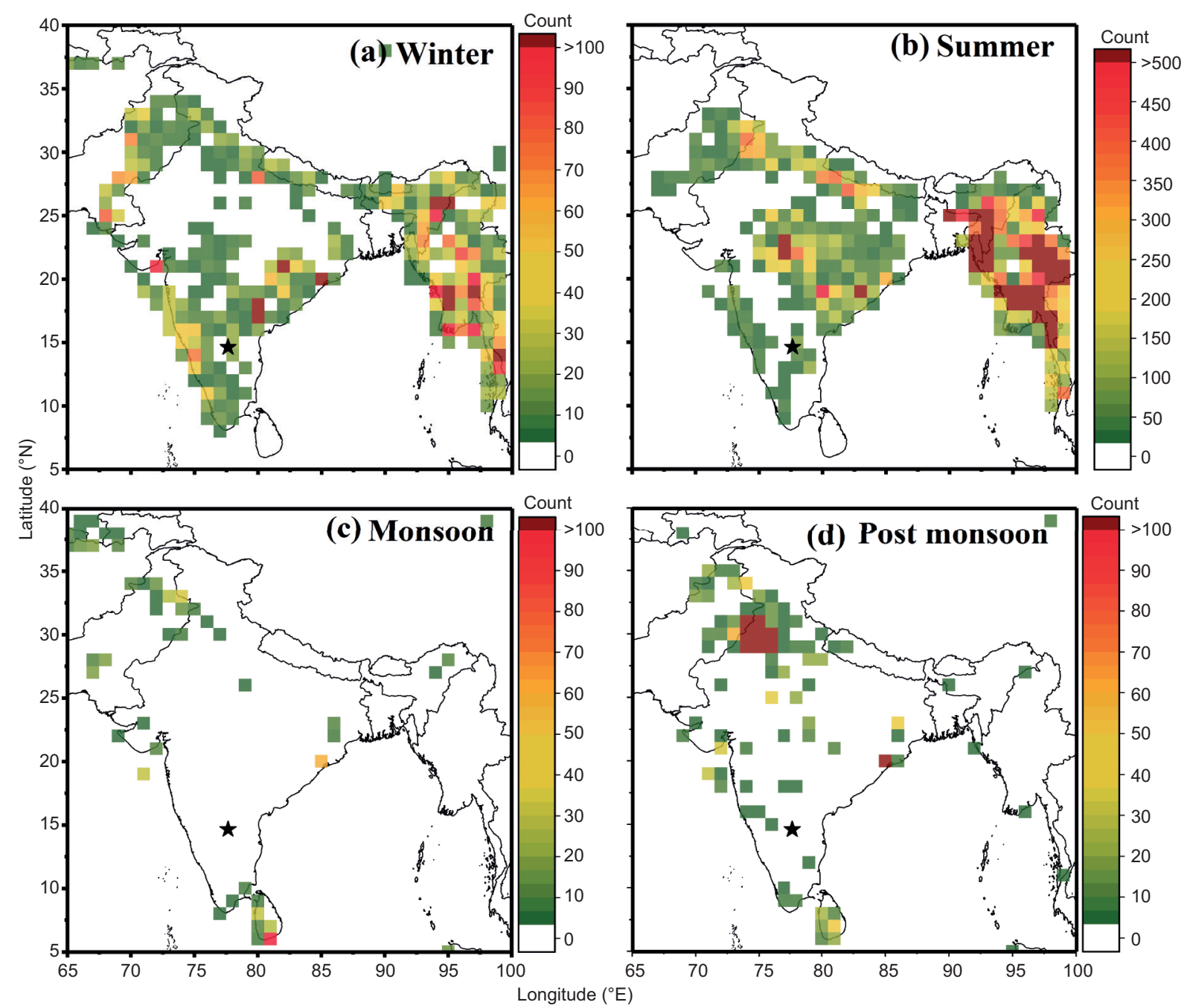

Fig. 7. MODIS cloud-corrected fire counts in different seasons during the study period. 
(a) Winter

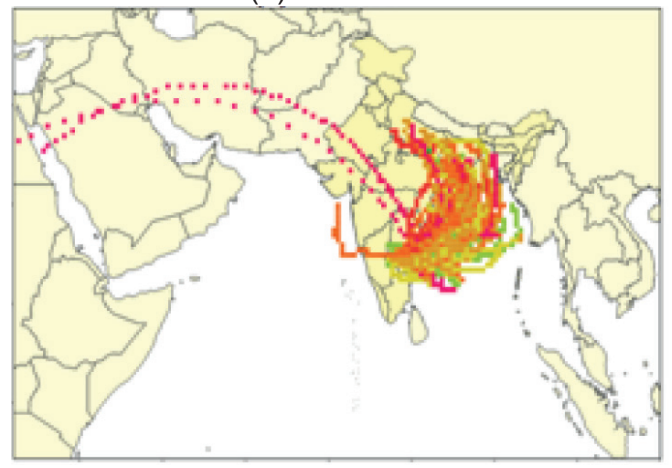

(c) Monsoon

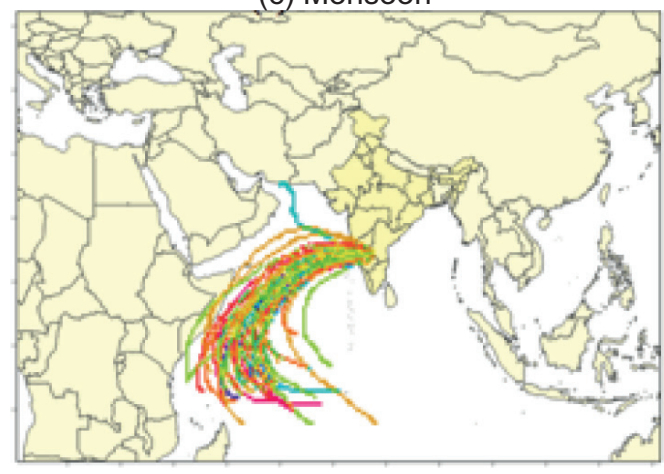

(b) Pre monsoon

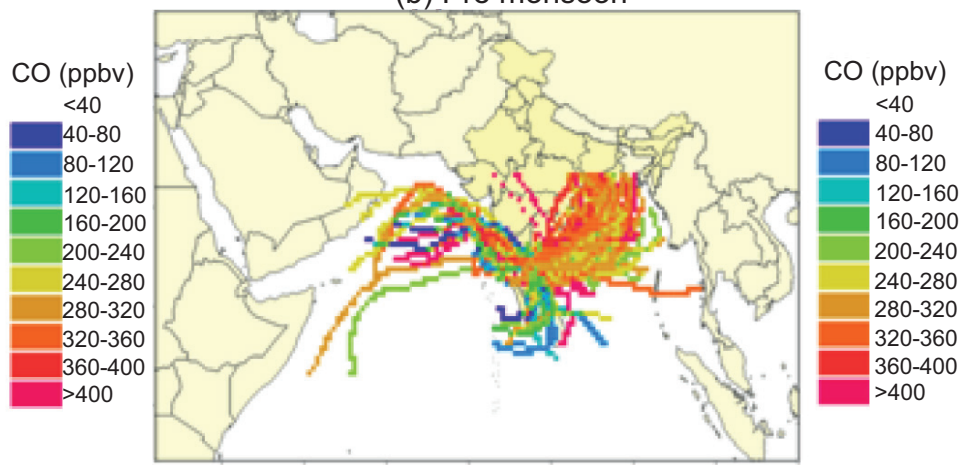

(d) Post monsoon

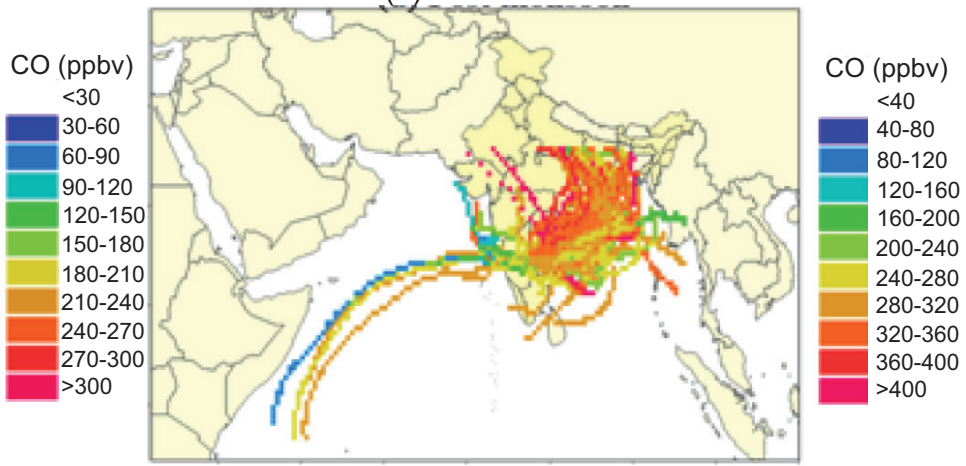

Fig. 8. Five-day isentropic HYSPLIT back-trajectories reaching over the study location in different seasons during the study period.

post-monsoon, although less fires befall over the IGB region, and most of the anthropogenic particles are removed by the washout process triggered by the southwest monsoon over the measurement location (Kalluri et al., 2016, 2017). During the monsoon, winds originate from the Arabian Sea and pollution from anthropogenic activities is removed by the washout process (Fig. 8c).

\subsection{Comparison with other sites in India}

It is interesting to compare our results with those obtained in other Indian regions (Table I). It can be seen that $\mathrm{CO}$ concentrations over the study region were greater than in a high altitude location (Nainital) and a rural location (Gadanki). However, it can also be noticed that $\mathrm{CO}$ concentration levels over polluted urban locations (Dehli, Agra, Kanpur) are more than twice compared with the present study location. Furthermore, the seasonal variation of $\mathrm{CO}$ levels at the study site and Udaipur was almost similar except for the post-monsoon. A large difference was observed in both regions during the post-monsoon due to s change in the direction of air masses. However, $\mathrm{CO}$ levels at the measuring site were higher than in Udaipur since in the latter farmers burned crop residues from agriculture activities.

\section{Conclusions}

In this study we presented a comprehensive analysis of $\mathrm{CO}$ concentrations using in-situ and MOPITT satellite observations from January 2016 to December 2017 over a semi-arid region in India (Anantapur). The important findings of the present study are summarized as follows:

- The seasonal mean variation of in-situ measured CO concentrations was highest $(329 \pm 52$ ppbv) during the winter and lowest $(192 \pm 22 \mathrm{ppbv})$ during the monsoon.

- Continental air masses dominated during winter and pre-monsoon, resulting in secondary peaks 
Table I. Comparison of CO concentration levels over Anantapur with those reported from a other locations in India.

\begin{tabular}{llcl}
\hline Station & \multicolumn{1}{c}{ Period } & Concentration (ppbv) & Reference \\
\hline New Delhi & 2000-2009 & $2940 \pm 1729$ & Chelani, 2012 \\
\hline Delhi & Jan 2013-Dec 2014 & $\begin{array}{c}2500 \pm 400(\text { PoM), } 2500 \pm 300(W), \\
2400 \pm 800(\mathrm{M})\end{array}$ & Tyagi et al., 2016 \\
\hline Agra & Nov 2003-Feb 2005 & $710 \pm 159.4$ & Renuka et al., 2008 \\
\hline Kanpur & Jun 2009-May 2013 & $721 \pm 403$ & Gaur, 2014 \\
\hline Ahmedabad & 2002 & $385 \pm 200$ & Sahu et al., 2006 \\
\hline Gadanki & 1993-1996 & $237 \pm 64$ & Naja and Lal, 2002 \\
\hline Nainital & 2009-2011 & $174 \pm 108$ & Sarangi et al., 2014 \\
\hline Udaipur & 2010-2011 & $462 \pm 85(\mathrm{~W}), 297 \pm 64(\mathrm{PM})$, & Yadav et al., 2014 \\
\hline Anantapur & Jan 2016-Dec 2017 & $329 \pm 52(\mathrm{~W}), 327 \pm 57(\mathrm{PM})$, & Present study \\
\hline Kathmandu Valley & Dec 2012-June 2013 & $234 \pm 36(\mathrm{M}), 192 \pm 22(\mathrm{PoM})$ & \\
\hline Agra & Mar 2015 - Feb 2016 & $770 \pm 466$ ppb (W), $466 \pm 301(\mathrm{PoM})$ & Verma et al., 2017 \\
& $232 \pm 223(\mathrm{PM}), 153 \pm 122(\mathrm{M})$ & \\
\hline
\end{tabular}

W: winter; PM: pre-monsoon; M: monsoon; PoM: post-monsoon.

of CO concentrations at high altitudes (200 hpa).

- The moderate correlation between $\mathrm{CO}$ and $\mathrm{BC}$ is noticed at the observation site, where measurements were influenced by emissions from various sources.

- The CWT analysis obtained from HYSPLIT suggests that except for the monsoon, air masses transported from central parts of India and the IGB region play a vital role in enhancing concentration levels at the receptor site.

\section{Acknowledgment}

The authors wish to thank the Indian Space Research Organization (ISRO), Bangalore, for carrying out this work through its Geosphere-Biosphere Programme (GBP) under the AT-CTM and ARFI project. We gratefully acknowledge the NOAA Air Resources Laboratory (ARL) and MOPITT for the provision of the HYSPLIT transport dispersion model used in this publication.

\section{References}

Akimoto H. 2003. Global air quality and pollution. Science 302: 1716-1719. https://doi.org/10.1126/ science. 1092666

Baumgardner D, Raga G, Peralta O, Rosas I, Castro T, Kuhlbusch T, John A, Petzold A. 2002. Diagnosing black carbon trends in large urban areas using carbon monoxide measurements. Journal of Geophysical Research: Atmospheres 107: ICC 4-1-ICC 4-9. https:// doi.org/10.1029/2001jd000626

Beig G, Gunthe S, Jadhav DB. 2007. Simultaneous measurements of ozone and its precursors on a diurnal scale at a semi urban site in India. Journal of Atmospheric Chemistry 57: 239-253. https://doi.org/10.1007/ s10874-007-9068-8

Bhardwaj P, Naja M, Rupakheti M, Lupascu A, Mues A, Panday AK, Rajesh K, Mahata KS, Shyam L, Harish CC, Lawrence MG. 2018. Variations in surface ozone and carbon monoxide in the Kathmandu Valley and surrounding broader regions during SusKat-ABC field campaign: role of local and regional sources. 
Atmospheric Chemistry and Physics 18: 11949-11971. https://doi.org/10.5194/acp-18-11949-2018

Chelani AB. 2012. Persistence analysis of extreme CO, $\mathrm{NO} 2$ and $\mathrm{O} 3$ concentrations in ambient air of Delhi. Atmospheric Research 108: 128-134. https://doi. org/10.1016/j.atmosres.2012.02.001

Dalvi M, Beig G, Patil U, Kaginalkar A, Sharma C, Mitra AP. 2006. A GIS based methodology for gridding of large-scale emission inventories: Application to carbon-monoxide emissions over Indian region. Atmospheric Environment 40: 2995-3007. https://doi. org/10.1016/j.atmosenv.2006.01.013

Draxler RR, Hess GD. 1997. Description of the HYSPLIT-4 modeling system. NOAA Technical memorandum ERL ARL-224. NOAA Air Resources Laboratory, Silver Spring, MD, USA.

Duncan BN, Logan JA, Bey I, Megretskaia IA, Yantosca RM, Novelli PC, Jones NB, Rinsland CP. 2007. Global budget of CO, 1988-1997: Source estimates and validation with a global model. Journal of Geophysical Research: Atmospheres 112: D22. https://doi. org/10.1029/2007jd008459

Emmons LK, Walters S, Hess PG, Lamarque JF, Pfister GG, Fillmore D, Granier C, Guenther A, Kinnison D, Laepple T, Orlando J, Tie X, Tyndall G, Wiedinmyer C, Baughcum SL, Kloster S. 2010. Description and evaluation of the Model for Ozone and Related Chemical Tracers, version 4 (MOZART-4). Geoscientific Model Development 3: 43-67. https://doi.org/10.5194/gmd-3-43-2010

Gaur A, Tripathi SN, Kanawade VP, Tare V, Shukla SP. 2014. Four-year measurements of trace gases (SO2, $\mathrm{NOx}, \mathrm{CO}$, and O3) at an urban location, Kanpur, in Northern India. Journal of Atmospheric Chemistry 71: 283-301. https://doi.org/10.1007/s10874-014-9295-8

Ghude SD, Beig G, Kulkarni PS, Kanawade VP, Fadnavis S, Remedios JJ, Kulkarni SH. 2011. Regional CO pollution over the Indian-subcontinent and various transport pathways as observed by MOPITT. International Journal of Remote Sensing 32: 6133-6148. https://doi. org/10.1080/01431161.2010.507796

Giglio L, Descloitres J, Justice CO, Kaufman YJ. 2003. An enhanced contextual fire detection algorithm for MODIS. Remote Sensing of Environment 87: 273282. https://doi.org/10.1016/s0034-4257(03)00184-6

Girach IA, Nair PR. 2014. Carbon monoxide over Indian region as observed by MOPITT. Atmospheric Environment 99: 599-609. https://doi.org/10.1016/j. atmosenv.2014.10.019
Girach IA, Nair PR. 2014. On the vertical distribution of carbon monoxide over Bay of Bengal during winter: Role of water vapour and vertical updrafts. Journal of Atmospheric and Solar-Terrestrial Physics 117: 31-47. https://doi.org/10.1016/j.jastp.2014.05.003

Gopal KR, Arafath SM, Lingaswamy AP, Balakrishnaiah G, Pavan Kumari S, Uma Devi K, Siva Kumar Reddy N, Raja Obul Reddy K, Penchal Reddy M, Reddy RR, Suresh Babu S. 2014. In-situ measurements of atmospheric aerosols by using Integrating Nephelometer over a semi-arid station, southern India. Atmospheric Environment 86: 228-240. https://doi.org/10.1016/j. atmosenv.2013.12.009

Gopal RK, Reddy ORK, Balakrishnaiah G, Arafath SM, Reddy KSN, Rao TC, Reddy LT, Reddy RR. 2016. Regional trends of aerosol optical depth and their impact on cloud properties over Southern India using MODIS data. Journal of Atmospheric and Solar-Terrestrial Physics 146: 38-48. https://doi.org/10.1016/j. jastp.2016.05.005

Gopal RK, Balakrishnaiah G, Arafath SM, Raja Obul Reddy K, Siva Kumar Reddy N, Pavan Kumari S, Mallikarjuna Reddy P. 2017. Measurements of scattering and absorption properties of surface aerosols at a semi-arid site, Anantapur. Atmospheric Research 183: 84-93. https://doi.org/10.1016/j.atmosres.2016.08.016 Hansen ADA, Rosen H, Novakov T. 1984. The aethalometer - An instrument for the real-time measurement of optical absorption by aerosol particles. Science of the Total Environment 36: 191-196. https://doi. org/10.1016/0048-9697(84)90265-1

Kalluri ROR, Gugamsetty B, Kotalo RG, Nagireddy SKR, Tandule CR, Thotli LR, Ramakrishna RR, Surendranair SB. 2016. Direct radiative forcing properties of atmospheric aerosols over semi-arid region, Anantapur in India. Science of the Total Environment 566: 10021013. https://doi.org/10.1016/j.scitotenv.2016.05.056 Kalluri ROR, Balakrishnaiah G, Rama Gopal K, Reddy KSN, ChakradharRao T, Lokeswara Reddy T, Nazeer Hussain S, Reddy VM, Reddy RR, Babu SS. 2017. Seasonal variation of near surface black carbon and satellite derived vertical distribution of aerosols over a semi-arid station in India. Atmospheric Research 184: 77-87. https://doi.org/10.1016/j.atmosres.2016.09.003

Kalluri ROR, Xiaoyu Z, Lei B. 2019. Seasonal aerosol variations over a coastal city, Zhoushan, China from CALIPSO observations. Atmospheric Research 218: 117-128. https://doi.org/10.1016/j.atmosres.2018.11.011 
Kalluri ROR, Xiaoyu Z, Lei B, Jiyao Z, Le Y, Rama Gopal K. 2020a. Carbonaceous aerosol emission reduction over Shandong province and the impact of air pollution control as observed from synthetic satellite data. Atmospheric Environment 222: 117150. https://doi. org/10.1016/j.atmosenv.2019.117150

Kalluri ROR, Gugamsetty B, Kotalo RG, Thotli LR, Tandule CR, Akkiraju B. 2020b. Long-term (2008-2017) analysis of atmospheric composite aerosol and black carbon radiative forcing over a semi-arid region in southern India: Model results and ground measurement. Atmospheric Environment 240: 117840. https:// doi.org/10.1016/j.atmosenv.2020.117840

Kar J, Bremer H, Drummond JR, Rochon YJ, Jones DBA, Nichitiu F, Zou J, Liu J, Gille JC, Edwards DP, Deeter MN, Francis G, Ziskin D, Warner J. 2004. Evidence of vertical transport of carbon monoxide from Measurements of Pollution in the Troposphere (MOPITT). Geophysical Research Letters 31: L23105. https://doi. org/10.1029/2004gl021128

Kar J, Jones DBA, Drummond JR, Attie JL, Liu J, Zou J, Nichitiu F, Seymour MD, Edwards DP, Deeter MN, Gille JC, Richter A. 2008. Measurement of low-altitude CO over the Indian subcontinent by MOPITT. Journal of Geophysical Research: Atmospheres 113: D16. https://doi.org/10.1029/2007JD009362

Kar J, Deeter MN, Fishman J, Liu Z, Omar A, Creilson JK, Trepte CR, Vaughan MA, Winker DM. 2010. Wintertime pollution over the Eastern Indo- Gangetic Plains as observed from MOPITT, CALIPSO and tropospheric ozone residual data. Atmospheric Chemistry and Physics 10: 12273-12283. https://doi.org/10.5194/ acp-10-12273

Kumar R, Naja M, Pfister GG, Barth M.C, Brasseur GP. 2013. Source attribution of carbon monoxide in India and surrounding regions during wintertime. Journal of Geophysical Research: Atmospheres 118: 1981-1995. https://doi.org/10.1002/Jgrd.50134

Lal S, Naja M, Subbaraya B. 2000. Seasonal variations in surface ozone and its precursors over an urban site in India. Atmospheric Environment 34: 2713-2724. https://doi.org/10.1016/S1352-2310(99)00510-5

Lal S, Sahu LK, Venkataramani S, Mallik C. 2012. Light non-methane hydrocarbons at two sites in the Indo-Gangetic Plain. J. Environ. Monit. 14: 1159. https:// doi.org/10.1039/c2em10682

Lawrence MG, Rasch PJ, von Kuhlmann R, Williams J, Fischer H, de Reus M, Lelieveld J, Crutzen PJ,
Schultz M, Stier P, Huntrieser H, Heland J, Stohl A, Forster C, Elbern H, Jakobs H, Dickerson RR. 2003. Global chemical weather forecasts for field campaign planning: predictions and observations of largescale features during MINOS, CONTRACE, and INDOEX. Atmospheric Chemistry and Physics 3: 267-289. https://doi.org/10.5194/acp-3-267-2003

Mahata KS, Panday AK, Rupakheti M, Singh A, Naja M, Lawrence MG. 2017. Seasonal and diurnal variations in methane and carbon dioxide in the Kathmandu Valley in the foothills of the central Himalayas. Atmospheric Chemistry and Physics 17: 12573-12596. https://doi.org/10.5194/acp-17-12573-2017

Mallik C, Lal S. 2013. Seasonal characteristics of SO2, $\mathrm{NO} 2$, and $\mathrm{CO}$ emissions in and around the Indo-Gangetic plain. Environ. Monit. Assess. 186: 1295-1310. https://doi.org/10.1007/s10661-013-3458-y

Naja M, Lal S., 2002. Surface ozone and precursor gases at Gadanki (13.5 N, 79.2 E), a tropical rural site in India. Journal of Geophysical Research: Atmospheres 107: 4197. https://doi.org/10.1029/2001JD000357

Nazeer Hussain S, Chakradhar Rao T, Balakrishnaiah G, Rama Gopal K, Raja Obul Reddy K, Siva Kumar Reddy N, Lokeswara Reddy T, Pavan Kumari S, Ramanjaneya Reddy P, Ramakrishna Reddy R. 2018. Investigation of black carbon aerosols and their characteristics over tropical urban and semi-arid rural environments in peninsular India. Journal of Atmospheric and Solar-Terrestrial Physics 167: 48-57. https://doi. org/10.1016/j.jastp.2017.10.010

Pan WL, Camberato JJ, Moll RH, Kamprath EJ, Jackson WA. 1995. Altering Source-Sink Relationships in Prolific Maize Hybrids: Consequences for Nitrogen Uptake and Remobilization. Crop Science 35: 3, 836. https:// doi.org/10.2135/cropsci1995.0011183x00350003003

Pozzer A, Zimmermann P, Doering UM, van Aardenne J,

Tost H, Dentener F, Janssens Maenhout G, Lelieveld J. 2012. Effects of business-as-usual anthropogenic emissions on air quality. Journal of Atmospheric and Solar-Terrestrial Physics 12: 6915-6937. https://doi. org/10.5194/acp-12-6915-2012

Rappengluck B, Schmitz R, Bauerfeind M, Cereceda-Balic F, Baer D, Jorquera H, Silva Y, Oyola P. 2005. An urban photochemistry study in Santiago de Chile. Atmospheric Environment 39: 2913-2931. https://doi. org/10.1016/j.atmosenv.2004.12.049

Reddy RR, Gopal KR, Narasimhulu K, Reddy LSS, Kumar KR, Ahammed YN, Azeem PA. 2008. Diurnal and 
seasonal variabilities in surface ozone and its precursor gases at a semi-arid site Anantapur $\left(14.62^{\circ} \mathrm{N}, 77.65^{\circ} \mathrm{E}\right.$, $331 \mathrm{~m}$ asl) in India. Int. J. Environ. Sci. Tech. 65: 247-265. https://doi.org/10.1080/00207230701844379

Reddy KRO, Balakrishnaiah G, Gopal K, Reddy NSK, Chakradhar Rao T, Reddy LT, Hussain NS, Reddy MV, Reddy RR, Boreddy SKR, Babu S. 2016. Long term (2007 - 2013) observations of columnar aerosol optical properties and retrieved size distributions over Anantapur, India using Multi Wavelength solar Radiometer. Atmospheric Environment 142: 238-250. https://doi. org/10.1016/j.atmosenv.2016.07.047

Renuka S, Satsangi GS, Ajay T. 2008. Concentration of surface $\mathrm{O} 3, \mathrm{NO} 2$ and $\mathrm{CO}$ during winter season at a semi-arid region-Agra. India. Indian J. Radio Space Phys. 37: 121-130. https://doi.org/10.1007/s10874014-9295-8

Sahu LK, Lal S, Venkataramani S. 2006. Distributions of $\mathrm{O} 3, \mathrm{CO}$ and hydrocarbons over the Bay of Bengal: A study to assess the role of transport from southern India and marine regions during September-October 2002. Atmospheric Environment 40: 4633-4645. https://doi. org/10.1016/j.atmosenv.2006.02.037

Sarangi T, Naja M, Ojha N, Kumar R, Lal S, Venkataramani S, Kumar A, Sagar R, Chandola HC. 2014. First simultaneous measurements of ozone, $\mathrm{CO}$, and NOyat a high-altitude regional representative site in the central Himalayas. Journal of Geophysical Research: Atmospheres 119: 1592-1611. https://doi.org/10.1002/ 2013jd020631

Seibert P, Kromp-Kolb H, Baltensperger U, Jost DT, Schwikowski M. 1994. Trajectory analysis of high-Alpine air pollution data. In: Air pollution modeling and its application X (Gryning SE, Millán MM, Eds.). Springer, Boston, MA ((NATO Challenges of Modern Society, vol 18). https://doi.org/10.1007/978-1-46151817-4_65

Sheel V, Sahu LK, Kajino M, Deushi M, Stein O, Nedelec P. 2014. Seasonal and interannual variability of carbon monoxide based on MOZAIC observations, MACC reanalysis, and model simulations over an urban site in India. Journal of Geophysical Research: Atmospheres 119: 9123-9141. https://doi.org/10.1002/2013jd021425 Tyagi S, Tiwari S, Mishra A, Hopke PK, Attri SD, Srivastava AK, Bisht DS. 2016. Spatial variability of concentrations of gaseous pollutants across the National Capital Region of Delhi, India. Atmospheric Pollution Research 7: 808-816. https://doi.org/10.1016/j. apr.2016.04.008

Verma N, Satsangi A, Lakhani A, Kumari KM, Lal S. 2017. Diurnal, Seasonal, and Vertical Variability in Carbon Monoxide Levels at a Semi-Urban Site in India. Clean Soil, Air, Water 45: 1600432. https://doi.org/10.1002/ clen.201600432

Weingartner E, Saathoff H, Schnaiter M, Streit N, Bitnar B, Baltensperger U. 2003. Absorption of light by soot particles: determination of the absorption coefficient by means of aethalometers. Journal of Aerosol Science 34: 1445-1463. https://doi.org/10.1016/s00218502(03)00359-8

Worden HM, Deeter MN, Frankenberg C, George M, Nichitiu F, Worden J, Aben I, Bowman KW, Clerbaux C, Coheur PF, de Laat ATJ, Detweiler R, Drummond JR, Edwards DP, Gille JC, Hurtmans D, Luo M, Martínez Alonso S, Massie S, Pfister G, Warner JX. 2013. Decadal record of satellite carbon monoxide observations. Atmospheric Chemistry and Physics 13: 837-850. https://doi.org/10.5194/ acp-13-837-2013

Yadav R, Sahu LK, Jaaffrey SNA, Beig G. 2014. Temporal variation of particulate matter (PM) and potential sources at an urban site of Udaipur in Western India. Aerosol and Air Quality Research 14: 1613-1629. https://doi.org/10.4209/aaqr.2013.10.0310

Yoon J, Pozzer A. 2014. Model- Simulated trend of surface carbon monoxide for the 2001-2010 decade. Atmospheric Chemistry and Physics 14: 10465-10482. https://doi.org/10.5194/acp-14-10465-2014 